\title{
ЦИФРОВИЗАЦИЯ КОНСОЛИДИРОВАННОЙ ФИНАНСОВОЙ ОТЧЕТНОСТИ В СТРАХОВОМ БИЗНЕСЕ
}

\author{
(C) 2021 Петрова О.А. \\ старший преподаватель Департамента бизнес-аналитики \\ Финансовый университет при Правительстве Российской Федерации, Россия, Москва \\ E-mail: OAPetrova@fa.ru
}

Составление консолидированной отчетности группы компаний - это трудоемкий и длительный процесс, для реализации которого необходимо большое количество человеческих и временных ресурсов. В связи с этим в последнее время особенно актуальна проблема оптимизации процесса составления консолидированной отчетности, так как решение данной проблемы позволяет существенно сократить затраты холдинга и, вместе с этим, повысить качество выпускаемой консолидированной отчетности.

Ключевые слова: учет, анализ, аудит, консолидированная финансовая отчетность, страхование

В первую очередь, для упрощения процедуры составления отчетности необходимо гармонизовать учетные политики консолидируемых компаний. В учетной политике материнской компании должны быть прописаны: рабочий план счетов (для целей российской системы бухгалтерского учета (РСБУ)), включающий синтетические и аналитические счета, порядок учета объектов и хозяйственных операций, основные принципы ведения учета и др. Компаниям, входящим в группу, следует формировать свои учетные политики таким образом, чтобы внутрифирменные документы не противоречили учетной политике материнской организации, а дополняли её. Это условие позволит минимизировать количество корректирующих проводок при составлении консолидированной отчетности.

Стоит отметить, что степень детализации рабочего плана счетов также имеет важное значение - развитый аналитический учет способствует ускорению и упрощению анализа движения и остатков по счетам и сокращению количества реклассов. Минимальный уровень детализации определен количеством информации, необходимой для составления требуемых форм отчетности и примечаний к ним, а также для расчета аналитических показателей. Например, при учете депозитов, размещенных компанией в кредитных организациях (счет 20601), будет эффективным введение следующей аналитики:

20601.01 - депозитные счета в банках в рублях сроком более 90 дней;
20601.02 - депозитные счета в банках в рублях сроком до 90 дней;

20601.03 - депозитные счета в банках в валюте сроком более 90 дней;

20601.04 - депозитные счета в банках в валюте сроком до 90 дней;

Данная детализация подходит для компании, учетная политика которой предусматривает рекласс средств с депозитных счетов в денежные средства, если срок погашения депозита составляет менее 90 дней после отчетной даты. Также введенные аналитические счета позволяют ускорить процесс формирования примечаний «Денежные и приравненные к ним средства» и «Счета и депозиты в банках» в разрезе валют.

Формат финансовой отчетности и примечаний, составленных по международным стандартам финансовой отчетности (МСФО) и по требованиям РСБУ, различны. Для использования информации, представленной в разрезе рабочего плана счетов для целей РСБУ, необходимо провести мэппинг - ввести счета, необходимые для формирования отчетности согласно МСФО, и сопоставить их с действующим рабочим планом счетов. Пример мэппинга представлен в таблице 1.

Существуют страховые холдинги, включающие в себя компании, занимающиеся, например, производственной деятельностью. В таких группах компаний велика вероятность того, что разработанный для материнской страховой компании план счетов будет недостаточен для учета деятельности дочернего предприятия. Вынужденной мерой в данном случае будет мо- 
Таблица 1.

\begin{tabular}{|l|l|l|}
\hline \multicolumn{2}{|c|}{ Счет РСБУ } & \multirow{2}{*}{ Счет МСФО } \\
\cline { 1 - 2 } \multicolumn{1}{|c|}{ № счета } & \multicolumn{1}{|c|}{ Название } & Процентные доходы \\
\hline 71001.01 & Доходы по остатку на расчетном счете & Процентные доходы \\
\hline 71001.02 & Проценты по займам, выданным физическим лицам & Страховые убытки урегулированные \\
\hline 71410.01 & Страховая выплата по ОСАГО & Страховые убытки урегулированные \\
\hline 71410.19 & Франшиза по автострахованию & Административные расходы \\
\hline 71802.01 & Зараб. плата штатным сотрудникам & Административные расходы \\
\hline 71802.08 & Компенсационные выплаты & \multicolumn{1}{|l}{} \\
\hline
\end{tabular}

дернизация плана счетов дочерней компании, а различия в учетных политиках будут нивелироваться в процессе консолидации с помощью соответствующих корректировок. Для оптимизации процесса составления консолидированной отчетности число таких корректировок должно быть минимальным (за счет максимально возможного уровня унификации проводимой учетной политики материнской и дочерних компаний).

Современные программные продукты содержат специальные настройки, позволяющие осуществлять первоначальный мэппинг счетов автоматически. Например, в рабочем плане счетов на субсчете к счету «Производные финансовые инструменты» отражаются курсовые разницы по премиям по опционам и результаты переоценки производных финансовых инструментов (ПФИ). Согласно требованиям МСФО, эти доходы отражаются обособленно, и в данном случае настройка автоматической классификации может иметь следующий вид:

- сумма по субсчету «Производные финансовые инструменты» относится к статье «Чистая прибыль от операций с иностранной валютой» за исключением результатов от переоценки ПФИ (прописывается критерий по номерам существующих ПФИ, запрещающий отражение сумм по операциям с указанными номерами);

- сумма по субсчету «Производные финансовые инструменты» в части результатов переоценки ПФИ относятся к статье «Чистая прибыль от операций с финансовыми инструментами, оцениваемыми по справедливой стоимости через прибыль или убыток» (согласно критерию, прописанному на основании номеров ПФИ).

Отметим, что качественно составленный план счетов по РСБУ позволяет реализовывать первоначальный мэппинг более эффективно за счет сокращения дополнительных критериев разнесения и отсутствия необходимости анали- за счетов на предмет появления новых критериев для реклассификации.

После завершения процедуры первичного мэппинга и формирования (при необходимости) реклассификационных проводок следует составление корректировок, служащих для приведения полученных данных по требованиям РСБУ к данным по стандартам МСФО. Как правило, на практике эта задача реализуется путем разработки Ведомости корректировок, которая содержит исчерпывающую информацию о максимальном круге возможных поправочных проводок, алгоритмах их расчета и техническом порядке составления корректировок.

Помимо типовых корректировок, содержащихся в Ведомости, в процессе деятельности холдинга могут возникать нестандартные хозяйственные операции, требующие анализа на предмет корректировки. Несмотря на разовый характер таких операций, по ним также следует прописать алгоритм проведения корректировок.

Осуществлять корректировочные проводки можно вручную или автоматически. В первом случае из бухгалтерских программ выгружаются данные, информацию приводят в нужную для целей МСФО форму. После этого полученные данные сравнивают с имеющимися данными по требованиям РСБУ и на разницу делают соответствующие корректировки. При автоматическом преобразовании данных эти процедуры выполняются специально настроенным модулем бухгалтерской программы.

Очевидно, что автоматизация процесса расчета данных для целей МСФО позволяет существенно сократить время, затрачиваемое на подготовку финансовой отчетности за счет устранения необходимости ручного внесения всех изменений в файлы МСФО с целью пересчета информации. Однако зачастую компании, составляющие холдинг, используют для осуществления бухгалтерского учета разные программы, 
и применение приведенного выше метода автоматизации становится невозможным. Исходя из этого, холдингу необходимо рассмотреть возможность использования единой программы для ведения бухгалтерского учета, при этом настроить ее на максимальный круг задач, чтобы любая компания группы могла применить их с минимальными модификациями.

Важную роль при внедрении идентичных бухгалтерских программ также играют человеческий и временной факторы. Для повышения эффективности работы сотрудники МСФО должны иметь доступ к самостоятельной выгрузке необходимой информации через удаленный доступ, чтобы избежать лишних временных затрат (при формировании запросов в дочерние компании и ожидании ответа снижается оперативность получения данных).

Итак, сократить сроки подготовки консолидированной финансовой отчетности и стои- мость внедрения автоматизированной системы возможно за счет:

- использования единой учетной политики по РСБУ для всех компаний группы;

- сближения учетной политики по РСБУ и МСФО, позволяющего минимизировать количество корректировок;

- введения в рабочий план счетов дополнительной аналитики, необходимой для составления отчетности в соответствии с МСФО;

- изначального определения такого уровня автоматизации, который будет оптимально соответствовать масштабам группы;

- организации повышения квалификации сотрудников службы МСФО;

- введения системы вознаграждений, связанной с соблюдением сроков предоставления информации, для бухгалтерских служб и для служб, подготавливающих отчетность в соответствии с МСФО.

\section{Библиографический список}

1. Положение Банка России от 27.02.2017 N 579-П (ред. от 28.02.2019) «О Плане счетов бухгалтерского учета для кредитных организаций и порядке его применения» (Зарегистрировано в Минюсте России 20.03.2017 N 46021) (с изм. и доп., вступ. в силу с 01.07.2019)

2. Дружиловская Т. Ю. Концептуальные основы МСФО: критический анализ новых подходов / Дружиловская T. Ю. // International accounting. - 2017. - № 10. - c.596-610.

3. Литвиненко М.И. Консолидированная финансовая отчетность в соответствии с новыми стандартами / М.: Изд-во Юрайт, 2019.

4. Петров А. М. Консолидированная финансовая отчетность и корпоративный контроль / - М.: Изд-во Центркаталог, 2019.

5. Плотников В.С. Анализ теоретических основ концепции консолидированной финансовой отчетности / Плотников В.С., Плотникова О.В.// International accounting. - 2017. - № 13. - с.752-767.

6. Петрова О.А. ПРОБЛЕМЫ РАЗВИТИЯ РЫНКА ФАКТОРИНГОВЫХ УСЛУГ / - Экономические науки, № 9, 2021 